\title{
The minimum wage remains significantly high in Morocco
}

\author{
Mohamed Abrich, Mohamed Amine Lahlou
}

University of Hassan I, Settat, Morocco

\begin{abstract}
Morocco passed minimum wage legislation as early as 1936 with the aim of defining minimum pay levels for employees in urban and rural areas. Decisions to increase the minimum wage (guaranteed minimum wage) and SMAG (minimum guaranteed agricultural wage), which serve as minimum wages in the non-agricultural and agricultural sectors, respectively, do not follow a pre-established timetable but arise from exchanges between different stakeholders within the framework of social dialogue. Since the early 2000s, around ten increases have been implemented on the minimum wage, however, no scientific publication analyzing their effects on the Moroccan economy has been carried out. Thus, the objective of the study published by BAM is to examine the impact of revaluations of the minimum wage on a set of macroeconomic variables of interest to the decision-maker. The study reviews the criteria for setting the minimum wage and its macroeconomic effects. Then on the stylized facts that characterize the minimum wage in Morocco, particularly in relation to wage distribution, employment, informality and youth unemployment. The study also explores the links between minimum wage, overall salary and employment. Finally, a simulation of the effects of the increase in the minimum wage on the Moroccan economy is carried out based on a more structural model derived from the IMF's FSGM model.
\end{abstract}

Keywords: SMIG, minimum wage remains, Morocco.

\section{INTRODUCTION}

At the start of the 21st century, many schools and schools of thought coexisted, exposing their sometimesopposed methodological conceptions and, consequently, leading to recommendations in terms of economic policies with the influence that we know on management. The latter, in fact, will often structure according to the type of model in which it is immersed. Keynesian currents will favor State intervention in the economy in order to act on the level of real demand with the ambition of countering situations of underemployment. Monetarist currents consider the influence of money to be relatively neutral on the real economy. Neoclassical currents favor analyzes at the non-aggregate level, at that of the firm in a free and open market, and generally advocate budgetary stability. The current of economic Marxism has shown its limits since the late 1990s. No longer used, it has seen its failure.

The influence of economic policy recommendations on management. The proliferation of often contradictory economic conceptions makes it difficult for political decision-makers. The latter experience serious difficulties in making a diagnosis of the situation with which they are confronted and, consequently, in proposing and developing corrective measures. The causes of the deterioration of the industrial situation and employment 
in various Western countries give rise to very different and often contradictory interpretations, consequently, paralyzing for the remedies to be brought to them which, in fact, can be contradicted. Major management trends put new practices into perspective through concrete, operational insights and sectoral analyzes of the company. To this end, "Corporate Governance", also called "Corporate Governance" or "Corporate Governance" concerns the organization of power within a company with a view to a better balance between management bodies, supervisory bodies and shareholders. On the one hand, this trend is moving towards flexibility, skills management, the environment, risk factors and "legalization", in many countries including France, flexibility is desired by companies to cope with to the vagaries of the economic situation in general, that of the markets in particular. As for skills management, it relates to the necessary (required) skills as defined by the reference documents for trades or jobs or to the skills held by people who allow their ability to hold a position to be assessed. The prerequisites or essential conditions for access to a profession (state diplomas, driving license, etc.), outside statutory conditions, fall within the field of skills.

On the other hand, it is moving towards taking into account the cultural dimension and the social responsibility of the company. Finally, this trend is concerned with various management factors influencing current organizations. Without being exhaustive, we can enumerate: nécess the requirements of project management, remote team management (teleworking), the cost of labor, time management, management by processes, innovation, management by project and by quality. As we can see, the management framework has changed due to the appearance of these numerous parameters such as the weight of the legal system, concerns related to the living environment at work, working time management, new employee behaviors and shifting the founding values of corporate culture.

The impact of technologies, changes in customer relations, new financial rules, sustainable development, and the shifting of management boundaries are five major trends that will continue to disrupt managerial practices in the years to come. At the start of the 21 st century, many schools and schools of thought coexisted, exposing their sometimes-opposed methodological conceptions and, consequently, leading to recommendations in terms of economic policies with the influence that we know on management.

The latter, in fact, will often structure according to the type of model in which it is immersed. Keynesian currents will favor State intervention in the economy in order to act on the level of real demand with the ambition of countering situations of underemployment. Monetarist currents consider the influence of money to be relatively neutral on the real economy. Neoclassical currents favor analyzes at the non-aggregate level, at that of the firm in a free and open market, and generally advocate budgetary stability. The current of economic Marxism has shown its limits since the late 1990s. No longer used, it has seen its failure.

The influence of economic policy recommendations on management. The proliferation of often contradictory economic conceptions makes it difficult for political decision-makers. The latter experience serious difficulties in making a diagnosis of the situation with which they are confronted and, consequently, in proposing and developing corrective measures. The causes of the deterioration of the industrial situation and employment

in various Western countries give rise to very different and often contradictory interpretations, consequently, paralyzing for the remedies to be brought to them which, in fact, can be contradicted. Major management trends put new practices into perspective through concrete, operational insights and sectoral analyzes of the company. To this end, "Corporate Governance", also called "Corporate Governance" or "Corporate Governance" concerns the organization of power within a company with a view to a better balance between management 
bodies, supervisory bodies and shareholders. On the one hand, this trend is moving towards flexibility, skills management, the environment, risk factors and "legalization", in many countries including France, flexibility is desired by companies to cope with to the vagaries of the economic situation in general, that of the markets in particular. As for skills management, it relates to the necessary (required) skills as defined by the reference documents for trades or jobs or to the skills held by people who allow their ability to hold a position to be assessed.

The prerequisites or essential conditions for access to a profession (state diplomas, driving license, etc.), outside statutory conditions, fall within the field of skills. On the other hand, it is moving towards taking into account the cultural dimension and the social responsibility of the company. Finally, this trend is concerned with various management factors influencing current organizations. Without being exhaustive, we can enumerate: the requirements of project management, remote team management (teleworking), the cost of labor, time management, management by processes, innovation, management by project and by quality. As we can see, the management framework has changed due to the appearance of these numerous parameters such as the weight of the legal system, concerns related to the living environment at work, working time management, new employee behaviors and shifting the founding values of corporate culture. The impact of technologies, changes in customer relations, new financial rules, sustainable development, and the shifting of management boundaries are five major trends that will continue to disrupt managerial practices in the years to come.].

\section{THE MINIMUM WAGE RATE IN MOROCCO}

Regarding the criteria for setting the minimum wage, the International Labor Organization (ILO) report on minimum wage systems of 2014 distinguished between different criteria used in countries around the world. This distinction is based on the explicit mention of criteria at the level of legal texts, since it is often customary for the determination of these criteria to be the subject of special articles at the level of labor regulations (Labor Code, labor relations law, etc.) (see fig. 1).

Other countries, on the other hand, do not mention any criteria in their legislation (flexible model). For example, the decision-maker in countries such as Switzerland, Tunisia and Fiji is not required to comply with specific regulatory constraints to set the level of the minimum wage. Therefore, these countries are considered to adopt a flexible model as long as they have no restrictions on the criteria for setting the minimum wage.

In Morocco, the minimum wage is set by government authorities after consultation with the social partners (representatives of employers and employees). There are currently two types of minimum wages depending on the sector of activity: the guaranteed minimum agricultural wage (SMAG) for agriculture and the guaranteed minimum interprofessional wage (SMIG) for the rest of the sectors of the economy. The purpose of this section is to study the impact of the revaluations of these wages on the Moroccan economy based on a retrospective analysis and an international benchmark.

The findings relating to the links between the minimum wage and the macroeconomic aggregates explored make it possible to draw the first conclusions on the past period, which will subsequently be compared with econometric and structural approaches. 


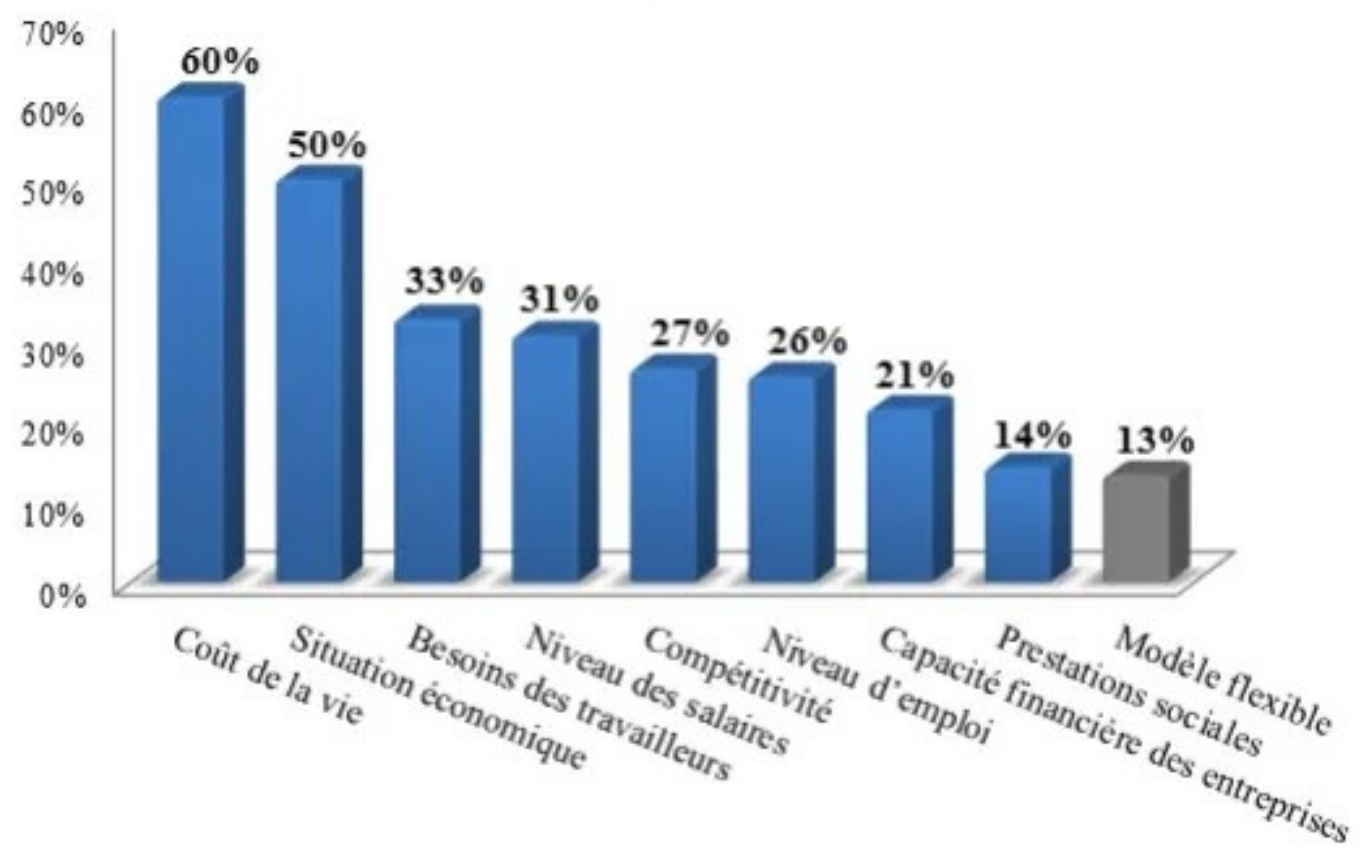

Figure 1: Use of minimum wage setting criteria around the world

Other countries, on the other hand, do not mention any criteria in their legislation (flexible model). For example, the decision-maker in countries such as Switzerland, Tunisia and Fiji is not required to comply with specific regulatory constraints to set the level of the minimum wage. Therefore, these countries are considered to adopt a flexible model as long as they have no restrictions on the criteria for setting the minimum wage. In Morocco, the minimum wage is set by government authorities after consultation with the social partners (representatives of employers and employees). There are currently two types of minimum wages depending on the sector of activity: the guaranteed minimum agricultural wage (SMAG) for agriculture and the guaranteed minimum interprofessional wage (SMIG) for the rest of the sectors of the economy. The purpose of this section is to study the impact of the revaluations of these wages on the Moroccan economy based on a retrospective analysis and an international benchmark. The findings relating to the links between the minimum wage and the macroeconomic aggregates explored make it possible to draw the first conclusions on the past period, which will subsequently be compared with econometric and structural approaches. This school brings together the works of Mayo, Lewin, Liker, Mc Gregor and Maslow. It was formed to react against classical and bureaucratic principles. She focused her analysis on the relationships between individuals and their motivation outside the perspective of monetary rewards.

Since the 1970s, in parallel with the rise of analyzes of the relative autonomy of sub-national territories, this notion of SSE has been asserted to designate a particular socio-economic logic, common to these specific companies (Demoustier, 2001). , increasingly recognized by the local public authorities, as likely to participate in a more dynamic and united territorial development, in terms of activities and jobs, as in terms of the way of life of the populations.

In fact, by mobilizing human, social, cultural, financial resources, etc., these forms of collective entrepreneurship attempt to "take advantage of all possible synergies" (du Tertre, 2000) [2], beyond the capacities of individual entrepreneurship. which they also encourage; Beyond the distinction between market 
and non-market activities, they internalize social costs within economic activity (integration, education, prevention, redistribution, etc.). Most of these companies, by mixing various resources (monetary or not) produce positive "externalities" on their environment. By advocating cooperation rather than competition between individuals, they contribute to social cohesion. Thus, the SSE provides both resources likely to increase the attractiveness of territories and generates a process likely to increase solidarity.

6Beyond a "postulated local" anchoring, the SSE can act as a "collective actor" of a "socially constructed territory" (Gilly, Lung, 2005) and thus participate in the "recomposition of productive potential" (Laurent, du Tertre, 2008) in certain areas.

The template is used to format your paper and style the text. All margins, column widths, line spaces, and text fonts are prescribed; please do not alter them. You may note peculiarities. For example, the head margin in this template measures proportionately more than is customary. This measurement and others are deliberate, using specifications that anticipate your paper as one part of the entire proceedings, and not as an independent document. Please do not revise any of the current designations.

\section{THE FIXING CRITERIA}

In 2019, the SMIG and the SMAG were respectively of the order of 2,698 DH and 1,903 DH per month, i.e. an hourly wage of $14.13 \mathrm{DH}$ and $9.15 \mathrm{DH}$. Since their inception, the two salaries have been revalued at the same time and at the same rate. Between 1999 and 2019, they were revalued ten times from an initial level of 1.659 $\mathrm{DH}$ for the minimum wage and $1.075 \mathrm{DH}$ for the monthly minimum wage. The average annual growth rate of the monthly minimum wage in Morocco over the period 1999-2015 was $2.6 \%$ for the SMIG and 3.1\% for the SMAG1. This was combined with an average annual growth in the average non-farm wage of around $3.6 \%$, compared to $5.3 \%$ for the average farm wage, according to HCP national accounts data.

In Morocco, the level of the minimum wage on the overall salary can be qualified as high. By correcting the wage in non-agricultural sectors, the importance of the minimum wage in Morocco remains a significant fact (around $43 \%$ of the average non-agricultural wage according to HCP data in 2015 and $59 \%$ of the average wage according to CNSS data in 2014) which may indicate positive effects on wages but nevertheless negative effects on employment. This observation is also supported by the international benchmark revealing that the minimum wage in Morocco is relatively high both in relation to the average wage and in relation to the level of GDP per capita.

An increase in the nominal minimum wage of 5\% leads, according to the study, to a maximum increase of $0.7 \%$ in real non-agricultural wages in the first quarter and to an acceleration of $2.7 \%$ in urban unemployment. The initial increase in the minimum wage is partially diffused to the wage distribution via renegotiation mechanisms, which explains the persistent, albeit moderate, effect which lasts for four quarters. In response to the increase in the cost of labor and in order to limit the job losses that may result from it, the productivity of workers increases and in turn shows respective increases of $0.53 \%$ and $0.48 \%$ over the first two quarters. . Ultimately, if revaluations of the SMIG in Morocco moderately increase wage income, however, this comes at the expense of an exacerbation of urban unemployment, limited in part by productivity gains.

This increase would have a moderate, albeit permanent, negative impact on the Moroccan economy. Nevertheless, the limited effects on the main macroeconomic variables, offset, moreover, by the adverse implications in terms of employment, would mainly be due to the size of the initial increase, which was set at $5 \%$. For larger recovery decisions, non-linearity effects should be taken into account. In other words, the drop 
in GDP that would be induced by a $10 \%$ increase in the minimum wage would be more than twice as high as the decrease caused by a $5 \%$ increase in this salary.

The minimum wage, according to the conclusion of the study, should be understood as an economic and social instrument carried out as part of a more comprehensive public redistribution policy. As such, the evaluation of the optimality of the minimum wage should take into account, in addition to the indicators presented in this work, other aspects related in particular to the social benefits granted to employees, the tax incentives in force and the business climate. from which employers' benefit.

By resorting to relative measures, such as minimum wage over average wage, this work attempts to capture some of these nuances by assuming that average compensation would largely reflect the average income workers need to meet their economic and social needs. However, despite this approximation, it would be difficult to understand other aspects relating to the quality of social benefits and the business climate. More indepth research is needed to better orient public action in this area.

For management scientists Stephen Robbins and Timothy Judge, organizational structure defines how work tasks are distributed, grouped and coordinated.

The structure describes the relationship of the various departments to each other and the hierarchical links: in this case the organization chart is a good reflection of the structure. For Henri Mintzberg (born in 1939), theorist and author in management, the structure "is the total sum of the means employed to divide the work between distinct tasks and then to ensure the necessary coordination between these tasks". The technical function of the structure emerges clearly from this definition: to provide the concrete means of division and coordination of work. Alain Desreumaux, University professor at IAE Lille, broadens the definition: "it is a set of devices according to which a company, or more generally an organization, distributes, coordinates, controls its activities and beyond orients or attempts to direct the behavior of its members ", For Stephen Robbins and Timothy Judge, management scientists, the organizational structure defines the way in which professional tasks are distributed, grouped and coordinated.

After these definitions, it should be noted that the authors of the book have chosen to present the work of Taylor, Fayol, Weber on the question of structure and organization. The classical school designates the set of approaches which, following the theories of Taylor or Fayol, have studied the organization of companies referring to a certain number of principles: the principle of unity of command; the principle of exception, very close to the principle of subsidiarity; optimizing the range of subordination; The principle of organizational specialization; the application of a scientific method. Many pioneers who have seen the effectiveness of a scientific organization of work. It should be mentioned that the work of Ricardo and especially of Adam Smith who, from 1776, describes the famous example of the manufacture of pins where workers, by a specialization of tasks (successive concepts along the production process) produce relatively much more than with production carried out by individuals working independently.

The industrial revolution, in about a century (nineteenth and early twentieth) incorporated three major major innovations that were the steam engine, electricity and telecommunications. These innovations will allow the creation and development of large companies based, on the one hand, on a high concentration of fixed capital leading to extensive social integration, and on the other hand, on the sale of products on important markets thus allowing the birth of big business. In France, Henry Fayol, beyond the technical dimension, strives to demonstrate that the administration of companies, that is to say their management, involves mastering a few key activities such as: Commercial activities (buying, selling, trading); financial activities (research and 
management of capital); Security (protection of goods and people); Accounting activities (inventory, balance sheet, cost price, etc.); Administrative or management activities (foresight, organization, command, coordination, control. And, all that is technology. Each position is called upon to implement a combination of several functions, positions being very loaded in terms of functions. administrative. The organization described by Max Wéber is one of the interesting developments of this time. The rational dimension, based on standards, procedures, skills, without personal preference, brings efficiency and freedom to everyone (outside of work). With the development of knowledge, innovation, teamwork (project-group), the requirement of social equity, Social Responsibility and the Company, the Classical School loses much of its relevance: from new organizational models are necessary to come, in addition or in substitution, to ensure the performance of the company.

\section{CONCLUSION}

By resorting to relative measures, such as minimum wage over average wage, this work attempts to capture some of these nuances by assuming that average compensation would largely reflect the average income workers need to meet their economic and social needs. However, despite this approximation, it would be difficult to understand other aspects relating to the quality of social benefits and the business climate. More indepth research is needed to better orient public action in this area.

\section{REFERENCES}

[1] REBEYROL P. et DECAP A.-S. (2010), « Apparition et développement des fondations dans le paysage juridique français du mécénat », Gestion \& Finances Publiques, n 12, décembre, pp. 918-922.

[2] GLÉMAIN P. (2018), « Appel public à entreprendre en proximité : une première évaluation du soutien régional au réseau France Active pour l'entreprendre "local". Le cas du FONDES en Pays de la Loire », in Altintas G. et Kustosz I. (coord.), Capacités entrepreneuriales : des organisations aux territoires », Caen, éditions ems-Management \& Société, pp. 161-187.

[3] GLÉMAIN P. et BILLAUDEAU V. (2018), « Finances solidaires et gestion des biens communs : l'expérimentation du Fonds de dotation Angers Mécénat », Marché \& Organisations, n 31, pp. 125-150.

[4] GLÉMAIN P. et LE DEN X. (2008), Évaluation du soutien régional à France Active, Rapport de recherche au Conseil Régional d'Île-de-France, Ramboll Management-Chaire ESS ESSCA EM.

[5] GOMPERS P. A. et LERNER J. (2001), « The Venture Kapital Revolution », Journal of Economic Perspectives, vol. 15, $\mathrm{n}^{\circ}$ 2, pp. $145-168$.

[6] GUÉRIN I. et VALLAT D. (2000), « Très petites entreprises et exclusion bancaire en France : les partenariats associationsbanques », Revue d'économie financière, ${ }^{\circ} 58, \mathrm{pp}$. 151-162.

[7] GUILHON B. et MONTCHAUD S. (2003), « Le capital à risque et les jeunes entreprises innovantes : problématique et enjeux », Revue internationale PME, vol. 16, nº 3-4, pp. 53-73.

[8] GURTNER E., JAEGER M. et ORY J.-N. (2002), « Le statut de coopérative est-il source dans le secteur bancaire ? », Revue d'économie financière, $n^{\circ} 67$, pp. 133-163. 